\title{
Efficiency of Some Traps to Measure Flux Dust Suspension Particles by Wind Erosion
}

\author{
Omnia M. Wassif \\ Soil Erosion Unit, Soil and Water Conservation Department, Desert Research Center (DRC), Cairo, Egypt
}

Received November 23, 2021; Revised January 15, 2022; Accepted January 25, 2022

\begin{abstract}
Cite This Paper in the following Citation Styles
(a): [1] Omnia M. Wassif, "Efficiency of Some Traps to Measure Flux Dust Suspension Particles by Wind Erosion," Universal Journal of Agricultural Research, Vol. 10, No. 1, pp. 38 - 52, 2022. DOI: 10.13189/ujar.2022.100104.
\end{abstract}

(b): Omnia M. Wassif (2022). Efficiency of Some Traps to Measure Flux Dust Suspension Particles by Wind Erosion. Universal Journal of Agricultural Research, 10(1), 38 - 52. DOI: 10.13189/ujar.2022.100104.

Copyright $\bigcirc 2022$ by authors, all rights reserved. Authors agree that this article remains permanently open access under the terms of the Creative Commons Attribution License 4.0 International License

\begin{abstract}
This study was to analyze the efficiency (E) of traps in holding suspended soil particles that cause dust, environmental and agricultural problems by wind erosion in NWCZ, Egypt. These vertical and passive sediment traps with different design in rotary and fixed reservoir box and different methods of measured soil loss. Rotary Distance (RD), Fixed Distance (FD), Rotary Point (RP) and Fixed Point (FP) traps were compared with traditional trap Big Spring Number Eight (BSNE). The variation between traps' efficiency as a function of height was significantly $(\mathrm{P} \leq 0.05)$ and was as follow: RD, FD, RP, and FP more increase than BSNE. The performance of the trap types as an efficiency of suspension particles (assumed to possess $\mathrm{E}=1$ for suspended particle sizes) was as follow RD> FD> RP> FP> BSNE; 99\%, 98\%, 88\%, 85\%, 65\% respectively. The efficiency of traps in suspension particles size $(<45,45-63$ and $>100 \mu \mathrm{m})$ were significant $(\mathrm{P} \leq 0.05)$ and the best efficient were RD and FD. Therefore, RD and FD traps have direct methods for measuring soil loss by wind erosion and have the most acceptable, accurate, fastest and easiest in soil particle analyzed and therefore the most effective way to discriminate suspension particles.
\end{abstract}

Keywords Dust Flux, Trap Suspension Efficiency, Horizontal Suspended Mass Flux, Passive Sediments, Vertical Traps

\section{Introduction}

Aeolian soil transport caused by wind erosion [1]. The wind erosion is that the major initiator of emission of soil particles worldwide which can cause serious agricultural and environmental problems, such as pollution [2], [3], [4] and [5]. It considered to be the the many part to move soil particles by wind sand disasters for human [6]. The definition of wind erosion consistent with [7] is the net long-term balance of wind processes that detach soil and move it from its original location. Wind erosion is one in all the foremost serious problems in arid regions which it occupies a 3rd of the world's area [8]. According to [9], 430 million ha of drylands, which comprise $40 \%$ of earth's surface are vulnerable to wind erosion. [10] reported that wind erosion in the NWCZ of Egypt may be a major problem in agriculture development and environment because sandy soils texture. This can be because, lack of soil structure, partial rock covering, limited plant covering and torrential characteristics of the rain [11]. For understand the hazards of wind erosion on agriculture and environment and therefore on human, it must be calculated the emission, transport, and deposition particles [6] and [12]. Soil particles size determines the patterns of soil motion in terms of creep, saltation, and suspension [13]. Passive sampling of airborne dust could be a common procedure in wind erosion and dust storm research. During such events many particles $>20 \mu \mathrm{m}$ are emitted from the soil [14]. Several studies concern about the saltation particles movement because it most vital parameter within the amount dust transported. Therefore, they concern to calculate the soil dust horizontal mass flux (HMF) [15], [14] and [16]. On the opposite hand, the suspended particles study in the air is important to understand the dust transport and how to deal with the risks wind erosion causes. Therefore, it is needed to calculate the amount of horizontal suspended particle mass flux (HSMF) [12]. It's 
crucial an important factor affecting the sampling efficiency when a sand sampler is employed to live the quantity of aeolian sand generated by wind erosion [6] and [17]. It depends on the structure of sand sampler, sand particle size and other factors [6]. Many soils eroded samplers designed and accustomed measure the fabric material carried by wind. A standard iso kinetic sampler doesn't discriminate between small particles and unbiased sample when collected sediment of the particle size distribution within the incident flow [18]. The common sampler used for study suspended particles has started since 1957 [8], [19] and [20]. Although the Big Spring Number Eight (BSNE) designed and described by [21]. BSNE is that the most used due to it's have advantages like near isokinetic sampling ability, large capacity, and low cost. Therefore, previous studies have shown that the efficiency of BSNE as a function of particle size was decreased with particle diameter relies on particle size [4], [18] and [19]. Additionally, BSNE has insufficient quantity of sediment to permit for adequate measurement of the transport flux [19]. Also, indirect way for measurement soil loss by wind erosion for dust concentration which calculated from transport flux. Its design didn't protect the gathering sediment from infiltration rain [4], [6], [16] and [17]. This study is comparing the sampling efficiency as a function of particle size for four traps as follow Rotary Distance (RD), Fixed Distance (FD), Rotary Point (RP) and Fixed Point (FP) with BSNE trap. Additionally, we'd like to understand the number of suspended particle flux and their transportation mechanism of how it is changing at different height of soil surface at study period time.

The objective of this study, evaluate the four sediment traps to beat the disadvantages of BSNE trap as function of particle size. Moreover, it had been evaluating the results for horizontal suspended particles mass flux (HSMF) and its variation with different heights. On the opposite hand, estimated of the trap's efficiency as a function of suspended particle size for eroded soil within the studied area.

\section{Material and Methods}

The experiment was conducted in 2020 and in an area about 1 ha at Wadi El Raml area, west Mersa Matrouh city and extended from southwest to northeast of the city. The latitudes of $31^{\circ} 09^{\prime} 00^{\prime \prime}, 31^{\circ} 21^{\prime} 00^{\prime \prime} \mathrm{N}$ and therefore the longitudes of $27^{\circ} 06^{\prime} 00^{\prime \prime}, 27^{\circ} 12^{\prime} 00^{\prime \prime} \mathrm{E}$. The particle size distribution of surface soil layer $(0-5 \mathrm{~cm})$ was $77.48 \%$ total sand $(66.9 \%$ coarse sand and $10.58 \%$ fine sand), $19.53 \%$ silt and $12.04 \%$ clay. The field is nearly flat. Table 1 shows some physical and chemical properties of the soil. Such properties were measured according to methods described by [22].

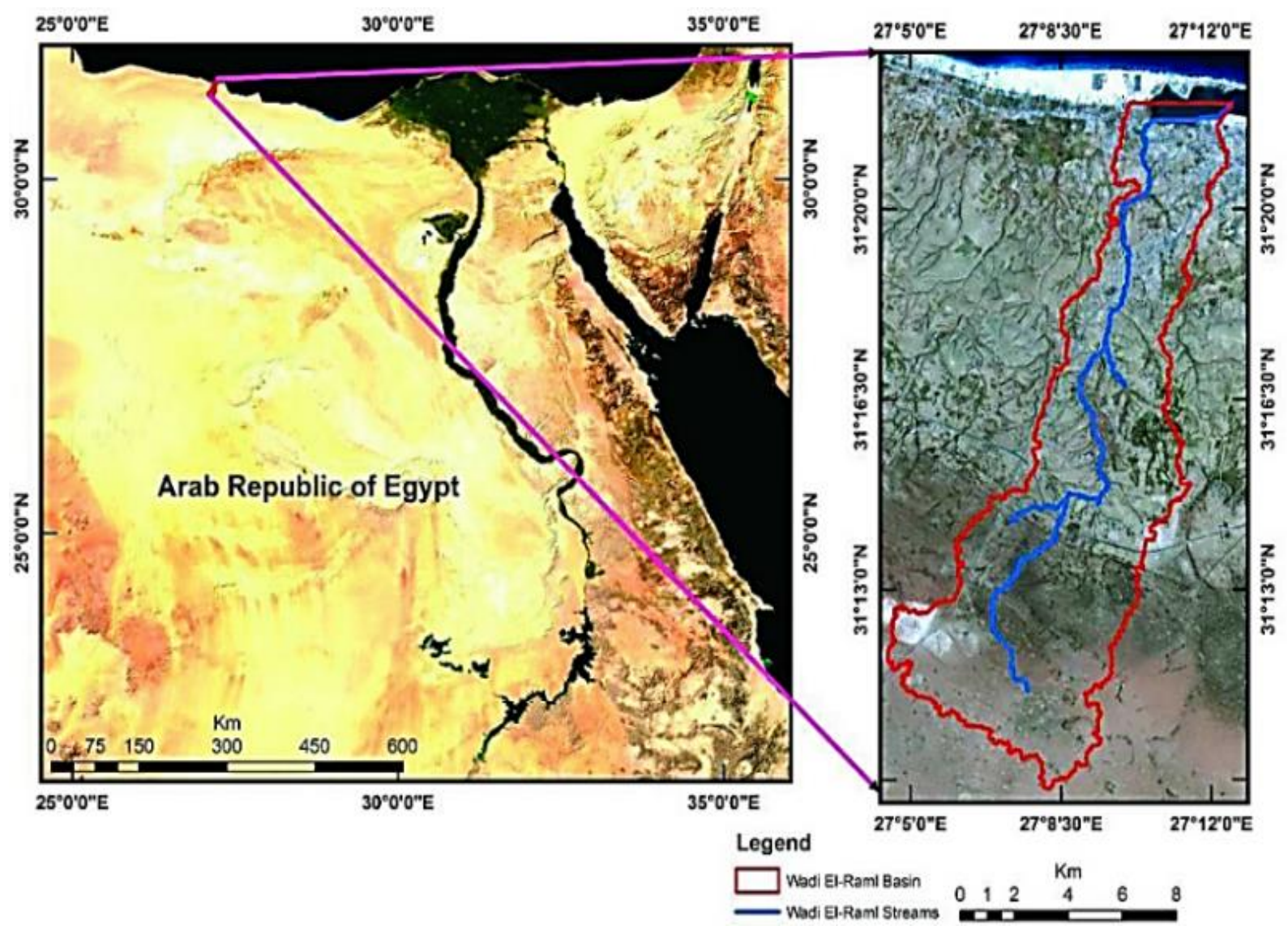

Figure 1. Map of location map of at Wadi El-Raml area, NWCZ of Egypt. 
Table 1. Some physical and chemical properties of surface soil layer $(0-5 \mathrm{~cm})$ at Wadi El-Ramal area, NWCZ, Egypt.

\begin{tabular}{|c|c|c|c|c|c|c|c|c|c|c|}
\hline \multicolumn{4}{|c|}{ Particle Size Distribution (\%) } & Texture class & $\begin{array}{c}\mathbf{B D}^{*} \\
\left(\mathbf{M g m}^{-3}\right)\end{array}$ & $\begin{array}{c}\text { O.M* } \\
\left(\mathbf{g K g}^{-1}\right)\end{array}$ & $\begin{array}{c}\text { T.N* } \\
\left(\mathbf{g K g}^{-1}\right)\end{array}$ & $\begin{array}{c}\mathbf{E C} \\
\mathbf{p H} \\
(\mathbf{d s} / \mathbf{m})\end{array}$ \\
\hline C.S* & F.S* & $\begin{array}{c}\text { Total } \\
\text { sand }\end{array}$ & S* & C & S. L* & 1.42 & 1.9 & 0.07 & 7.5 & 1.08 \\
\hline 66.9 & 10.58 & 77.48 & 19.53 & 12.04 & S. L & & & & \\
\hline
\end{tabular}

C. $\mathrm{S}=$ Coarse Sand, F. $\mathrm{S}=$ Fine Sand, BD= Bulk density, $\mathrm{OM}=$ Organic matter, $\mathrm{T}$. $\mathrm{N}=$ Total nitrogen.

Table 2. Monthly means of meteorological records during 2020 for Wadi El Raml area, NWCZ, Egypt

\begin{tabular}{ccccc}
\hline Month & Temperature $\left({ }^{\circ} \mathbf{C}\right)$ & Wind speed $(\mathbf{m} / \mathbf{s})$ & Rainfall $(\mathbf{m m})$ & Moisture $(\boldsymbol{\%})$ \\
\hline January & 13.10 & 7.62 & 1.86 & 35.84 \\
Febrauray & 13.64 & 6.74 & 1.33 & 37.02 \\
March & 14.85 & 7.23 & 2.18 & 35.16 \\
April & 16.85 & 6.78 & 0.04 & 34.44 \\
May & 20.87 & 6.63 & 0.00 & 31.97 \\
June & 23.35 & 6.27 & 0.00 & 31.73 \\
July & 26.22 & 5.77 & 0.00 & 31.77 \\
August & 27.18 & 5.67 & 0.00 & 32.49 \\
September & 26.58 & 5.60 & 0.00 & 33.16 \\
October & 23.95 & 5.49 & 0.42 & 33.19 \\
November & 18.67 & 5.92 & 7.20 & 35.70 \\
December & 15.76 & 7.52 & 0.16 & 37.19 \\
\hline
\end{tabular}

This area is suffering from wind erosion which is a serious problem for agricultural productivity. Consequently, evaluation of wind erosion and the flux suspended particles is vital and necessary. Samples of eroded soil were collected from Jan. to Dec. 2020. Table (2) shows the monthly means of meteorological records by [23]. Four trap types were used to collect the eroded soil and comparing with BSNE in terms of the efficiency of them for catching or holding the suspended of eroded soil.

\subsection{Trap Characteristics}

The five trap types were different in measured method of collected eroded soil and moving of reservoir box with wind direction as follow: a) Rotary Distance trap (RD) and Fixed Distance trap (FD) were had direct measurement method of eroded soil collected and rotary reservoir boxes in RD but fixed in FD. Otherwise, Rotary Point trap (RP) and Fixed-Point trap (FP) (Fig. 2 and 3). Which, all of them designed as vertically, and passive trap types. It is collecting soil particles at points distributed along the vertical distance extending from the soil surface to a height of one meter above the soil surface at distances $(15,32.5$, 55 and $100 \mathrm{~cm}$ ), respectively. These traps compared with Big Spring Number Eight (BSNE) dust traditional sampler trap described by [21].

Each trap is attached to a wind vane which can swing with the wind direction. In each reservoir box for traps RD, FD, RP, and FP have three stainless steel screens in the opening sampler for dust entering 140, 140-35 and 35 meshes that corresponds to $100,100-500$ and $500 \mu \mathrm{m}$ in diameter, respectively as described by [24]. Consequently, each reservoir box is divided into 3 sections in terms of soil particle size as follows $>140$ mesh $(500 \mu \mathrm{m}), 140-35$ mesh $(100-500 \mu \mathrm{m})$ and $<35$ mesh $(<100 \mu \mathrm{m})$. The opening BSNE samplers have 140 mesh $(125 \mu \mathrm{m})$ stainless steel screen. So, each reservoir box has one section of particle size is $<140$ mesh $(<125 \mu \mathrm{m})$. Otherwise, The FP and FR traps are designed in such a way that can store the eroded soil particles that enter the trap from different directions. The MR, FR were designed for measured the eroded sample as a direct way. This is mean that doesn't need mass flux transport to measure it. Otherwise, the MP, FP and BSNE designed for measured by indirect way. The main reason for designing these traps is the importance of measuring transmitted sediments from different wind directions. In addition, all slot of each trap designed to determine the horizontal suspended mass flux (HSMF) resulted from suspension particles sampled by sampler as result of wind erosion. All traps were installed on the equal distances about $100 \mathrm{~m}$ diameter and with the same heights $15(5,10), 30,50$ and $100 \mathrm{~cm}$ of the soil surface [25].

The dimensions of RD and FD traps consists of receiver opening of this instrument is in the form of a narrow vertical slot 10 and $5 \mathrm{~cm}$ in width respectively, and $30 \mathrm{~cm}$ height. In addition, the MP and FP traps has $5 \mathrm{~cm}$ high by 10 and $5 \mathrm{~cm}$ wide vertical slot, respectively. 


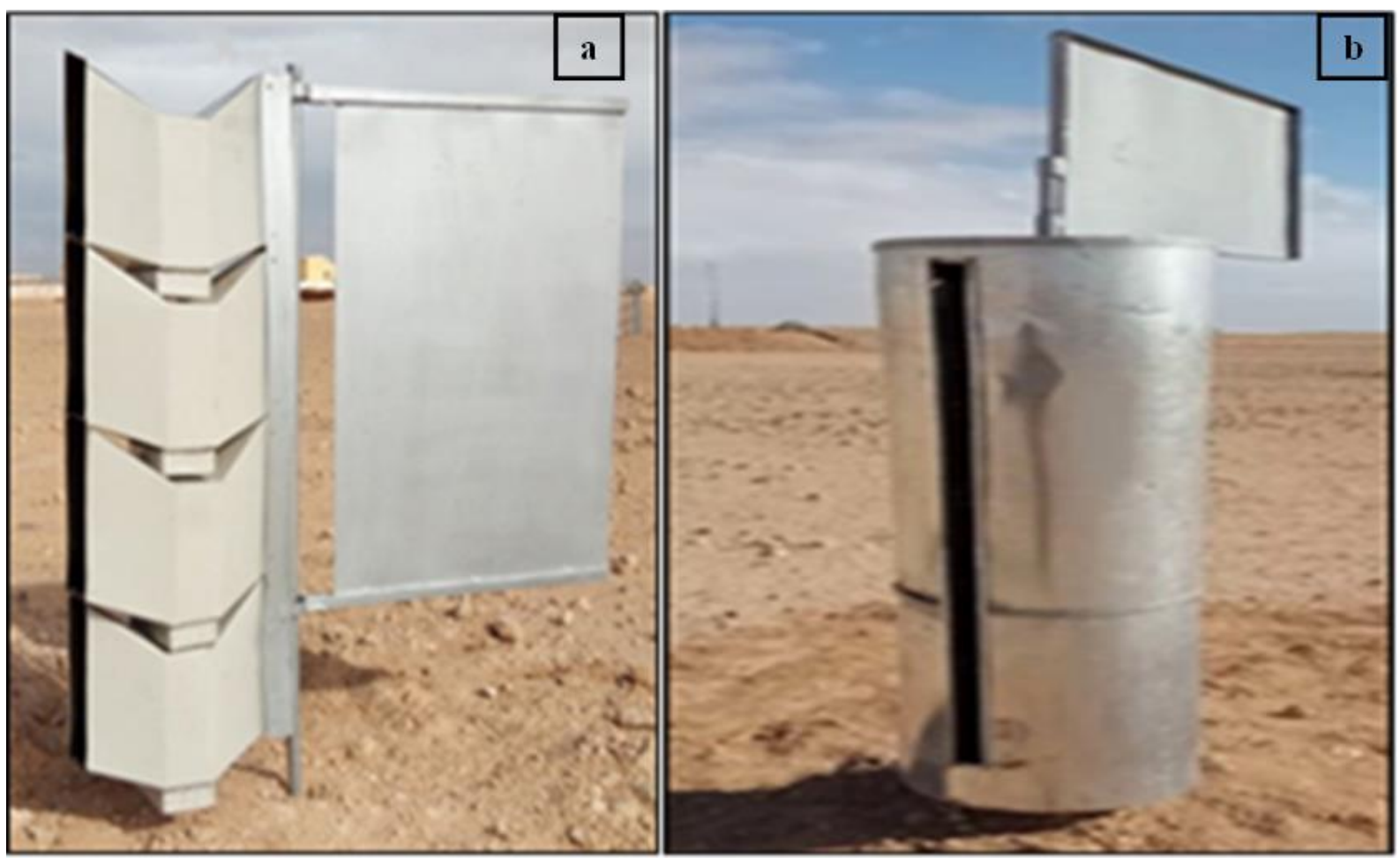

Figure 2. (a) is Rotary Distance trap (RD) and (b) is Fixed Distance trap (FD)

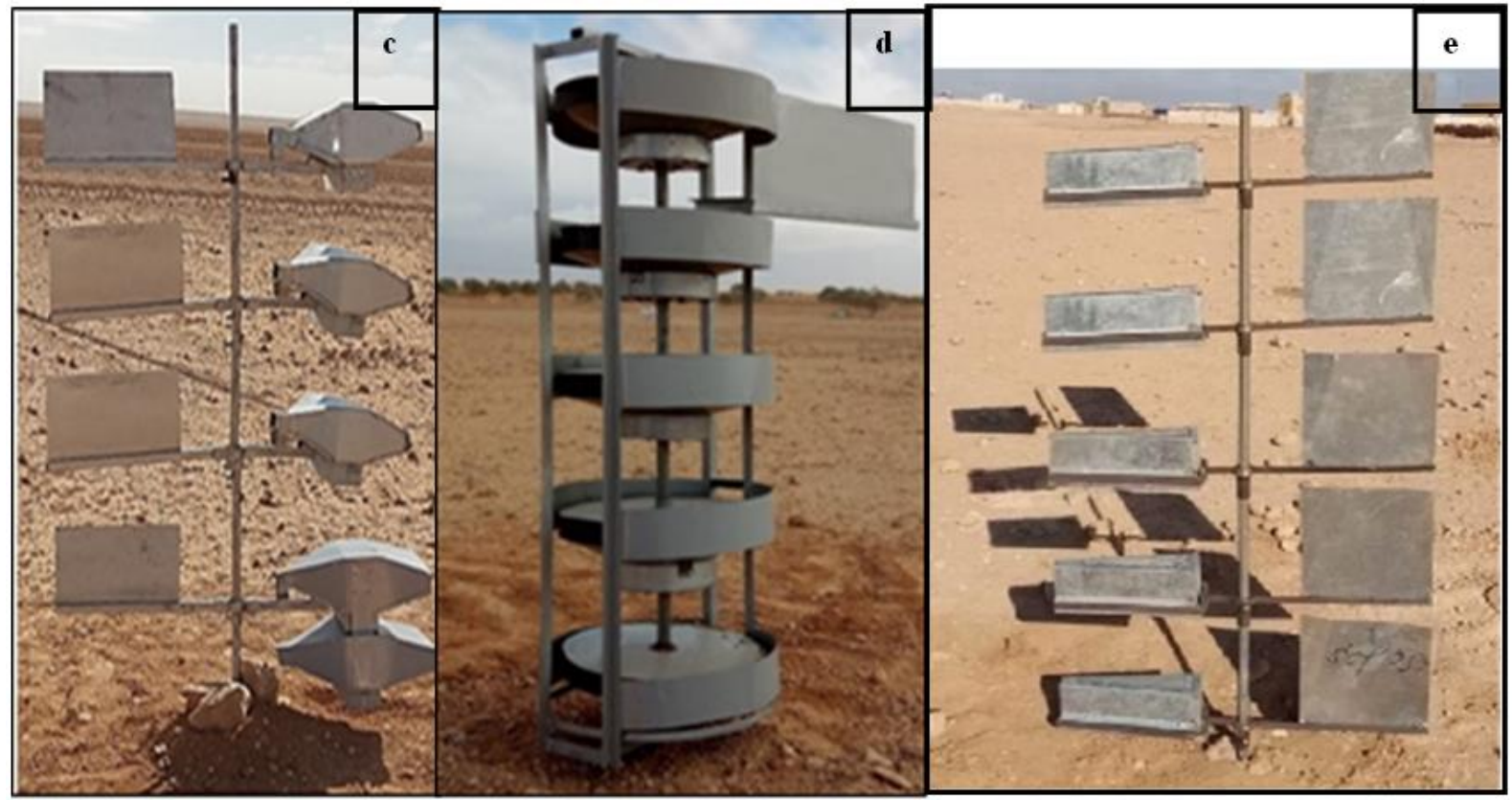

Figure 3. (c) The Rotary Point trap (RP), (d) the Fixed-Point trap (FP) (e) the Big Spring Number Eight (BSNE) trap

The BSNE trap with opening $2 \mathrm{~cm}$ wide and $10 \mathrm{~cm}$ height were used [26].

\subsection{Procedures for Collecting and Analyzing Eroded Soil Samples}

Eroded soil samples were collected after each month during experimental period. The horizontal suspended mass flux (HSMF) $\left(\mathrm{kg} / \mathrm{m}^{2} /\right.$ year), the amount of suspended soil particles passing by unit area of vertical plane in each individual sampler soil. It calculated by the formula in equation (1) as described by [27].

$$
F=W / S . T
$$

Where $\mathrm{F}=$ horizontal flux of suspension particles $\left(\mathrm{kg} / \mathrm{m}^{2} /\right.$ year $), \mathrm{W}=$ weight of suspension particles sampled by sampler $(\mathrm{kg}), \mathrm{S}=$ area of sampler opening $\left(\mathrm{m}^{2}\right)$ and $\mathrm{T}=$ 
time (year).

Equation (2) that described by [17] was used to evaluate the efficiency $(\mathrm{E} \%)$ for suspended particles of each trap as a function of particle size

$$
E=m / S Y
$$

Where $\mathrm{m}=$ the mass of suspended particles collected in the sampler, $\mathrm{S}=$ the sediment supply and $\mathrm{Y}=$ lateral width.

\subsection{Statistical Analysis}

Data were analyzed by the Computer Program, [27], using the General Linear Model (GLM) procedure. The significant differences among treatments means were evaluated by Duncan's Multiple Range-Test [28].

\section{Result and Discussion}

\subsection{Quantity of Soil Loss by Wind Erosion as a Function of Particle Size Distribution}

Total soil loss values by wind erosion ( $\mathrm{kg}$.cm width. $\mathrm{y}^{-1}$ ) are given in Table (3). As shown the total soil loss in the five types of traps were as follow $\mathrm{RD}>\mathrm{FD}>\mathrm{RP}>\mathrm{FP}>\mathrm{BSNE}$ respectively. Therefore, probably due to the larger opening of traps size cause the potential collected soil samples increase according to [14] and [18]. In addition, it is probably due to the highest of collection efficiency as follow $\mathrm{RD}>\mathrm{FD}>\mathrm{RP}>\mathrm{FP}>\mathrm{BSNE}$ as agreement with [24] and [29]. In addition, there were different between eroded soil weight at sampler from 15 to $100 \mathrm{~cm}$ height due to the particle movement type in each height (suspension saltation - creeping) [21]. Which, the lowest sampler weight was the particle movement by suspension and the highest weight was the particle moved by creeping and saltation [30]. As it known, wind speed increases with the height and the weight of soil particles decreased according to [20] and [21]

\subsection{The Relationship between Horizontal Suspended Flux and Height (HSMF)}

Previous researchers were focused on the variation in saltation aolian sediment flux as a function of height, consequently this study focused on suspension particles flux as a function of height. The relationship between HSMF and height from soil surface was described by power equation (3) and given in Table (3).

$$
\int(z)=a z^{b}
$$

Where $f(z)$ is the horizontal suspended particle's mass flux $\left(\mathrm{kg} . \mathrm{cm}^{2} \cdot \mathrm{y}^{-1}\right)$ at height $\mathrm{z}(\mathrm{cm})$ and $\mathrm{a}, \mathrm{b}$ are regression coefficients [12], [15] and [31]. In this respect other authors concluded that power function could better describe this variation. The variation in HSMF collected by RD, FD, RP, FP and BSNE traps as a function of height from soil surface during the study period (Fig. 4 and 5).

In this context, HSMF values in all trap types were increased with increasing height from soil surface and it is agreement with [6]. This result contrasts with the relationship of the horizontal mass flux (HMF) with height as a function of particle size. Which, it is decreased with height because the HMF includes the three types of particles size movements (creeping, saltation, and suspension particles) as described by [6]. Result in Table 4 showed the regression equations were described the variation between HSMF as a function of height for trap types by significant $(\mathrm{P} \leq 0.05)$. Therefore, the $\mathrm{RD}$ and $\mathrm{FD}$ traps were the highest significant in $100 \mathrm{~cm}$ height (Fig. 4 and 5). Otherwise, there was unsignificant different between the RP and FP traps in the same height. That is meaning RP and FP more or less the same. On the other hand, the significant of mean HSMF for traps were as follow $\mathrm{RD}>\mathrm{FD}>\mathrm{FP}=\mathrm{RP}>\mathrm{BSNE}$. 
Table 3. Total soil loss for RD, FD, RP, FP and BSNE traps in different proposed events (Jan.2020 to Jan.2021) under field measurement

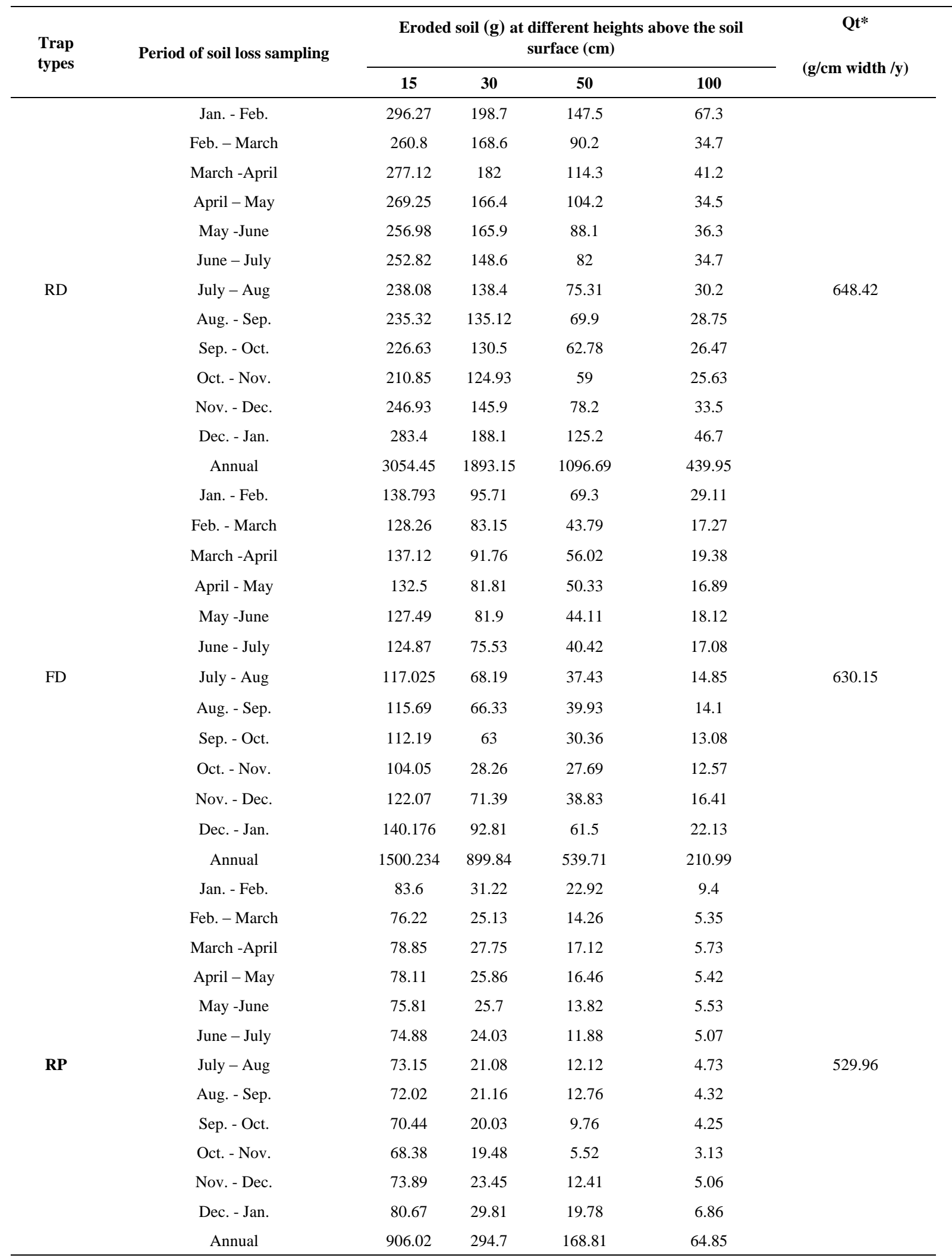


Table 3 Continued

\begin{tabular}{|c|c|c|c|c|c|c|}
\hline \multirow{2}{*}{$\begin{array}{l}\text { Trap } \\
\text { types }\end{array}$} & \multirow{2}{*}{$\begin{array}{c}\text { Period of soil loss } \\
\text { sampling }\end{array}$} & \multicolumn{4}{|c|}{ Eroded soil (g) at different heights above the soil surface $(\mathrm{cm})$} & \multirow{2}{*}{$\begin{array}{c}\mathbf{Q t}^{*} \\
(\mathrm{~g} / \mathrm{cm} \text { width } / \mathrm{y})\end{array}$} \\
\hline & & 15 & 30 & $\mathbf{5 0}$ & 100 & \\
\hline \multirow{12}{*}{ FP } & Jan. - Feb. & 39.42 & 14.76 & 10.97 & 4.04 & \multirow{12}{*}{529.27} \\
\hline & Feb. - March & 36.89 & 11.8 & 6.61 & 2.42 & \\
\hline & March -April & 37.91 & 13.15 & 8.03 & 2.61 & \\
\hline & April - May & 37.83 & 12.2 & 7.57 & 2.55 & \\
\hline & May -June & 35.89 & 11.98 & 6.07 & 2.69 & \\
\hline & June - July & 36.42 & 11.51 & 5.49 & 2.34 & \\
\hline & July - Aug & 35.73 & 10.13 & 5.69 & 2.16 & \\
\hline & Aug. - Sep. & 34.77 & 10.36 & 6.32 & 1.8 & \\
\hline & Sep. - Oct. & 34.31 & 10.09 & 4.53 & 2.03 & \\
\hline & Oct. - Nov. & 33.18 & 9.22 & 2.74 & 1.49 & \\
\hline & Nov. - Dec. & 32.6 & 11.28 & 5.08 & 2.45 & \\
\hline & Dec. - Jan. & 39.36 & 14.13 & 9.17 & 3.29 & \\
\hline \multirow{14}{*}{ BSNE } & Annual & 434.31 & 140.61 & 78.27 & 29.87 & \multirow{14}{*}{308.74} \\
\hline & Jan. - Feb. & 9.9 & 5.18 & 4.32 & 1.5 & \\
\hline & Feb. - March & 6 & 4.63 & 2.26 & 0.9 & \\
\hline & March -April & 7.5 & 5.23 & 5.07 & 1.02 & \\
\hline & April - May & 6.5 & 4.29 & 2.99 & 0.98 & \\
\hline & May -June & 5.5 & 4.52 & 2.41 & 1.06 & \\
\hline & June - July & 5 & 4.56 & 2.07 & 0.95 & \\
\hline & July - Aug & 4.1 & 3.789 & 2.01 & 0.84 & \\
\hline & Aug. - Sep. & 4 & 4.19 & 2.1 & 0.62 & \\
\hline & Sep. - Oct. & 4 & 3.89 & 1.46 & 0.51 & \\
\hline & Oct. - Nov. & 4.2 & 3.21 & 1.06 & 0.42 & \\
\hline & Nov. - Dec. & 4.5 & 4.48 & 2.03 & 0.9 & \\
\hline & Dec. - Jan. & 8 & 5.43 & 3.52 & 1.2 & \\
\hline & Annual & 69.2 & 53.399 & 31.3 & 10.9 & \\
\hline
\end{tabular}

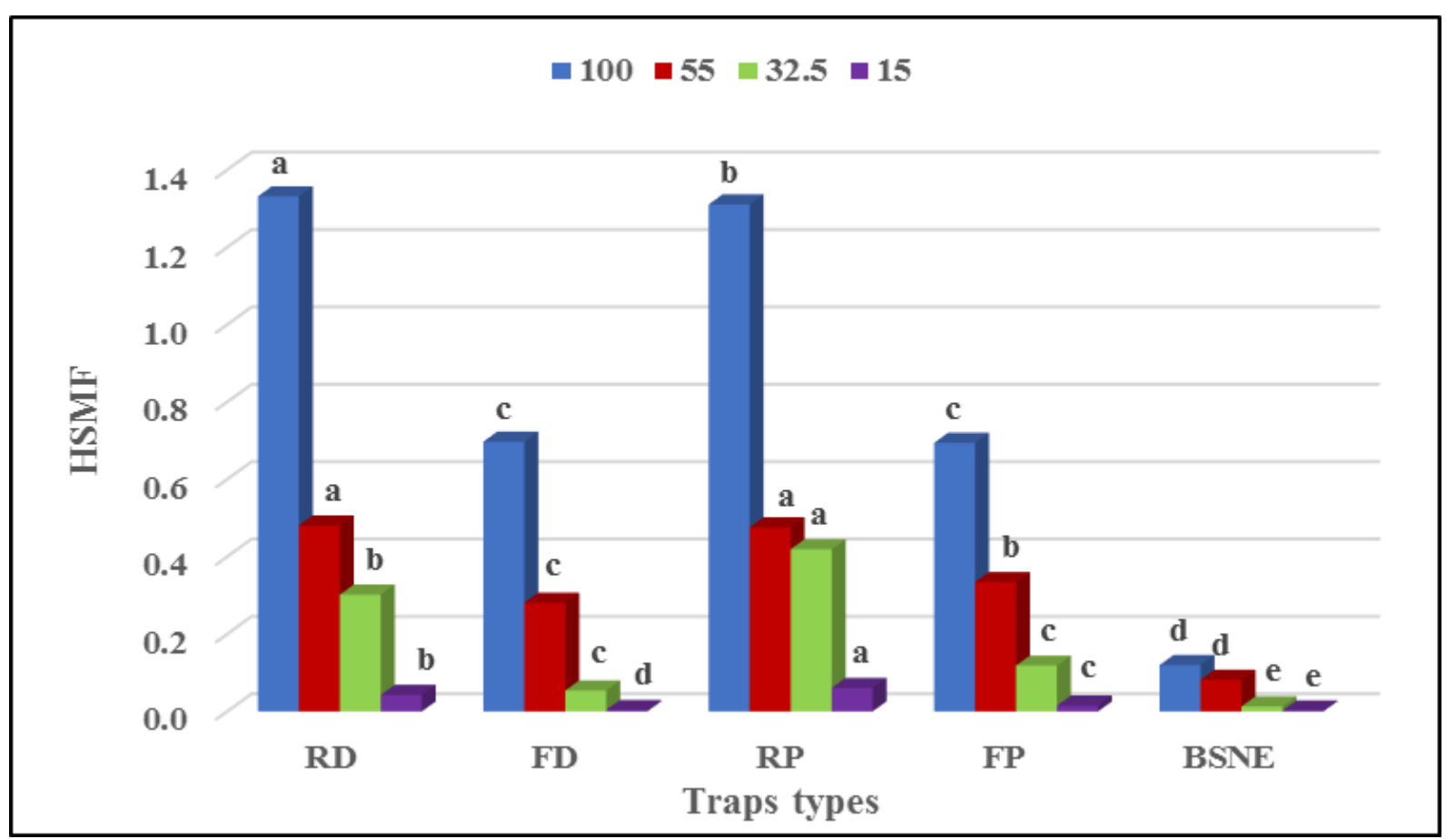

Figure 4. Variation between HSMF of the trap types and heights (10,32.5,55 and $100 \mathrm{~cm})$ (from Jan. 2020 until Dec. 2020); Values followed by different letters are significantly at $p<0.05$. 


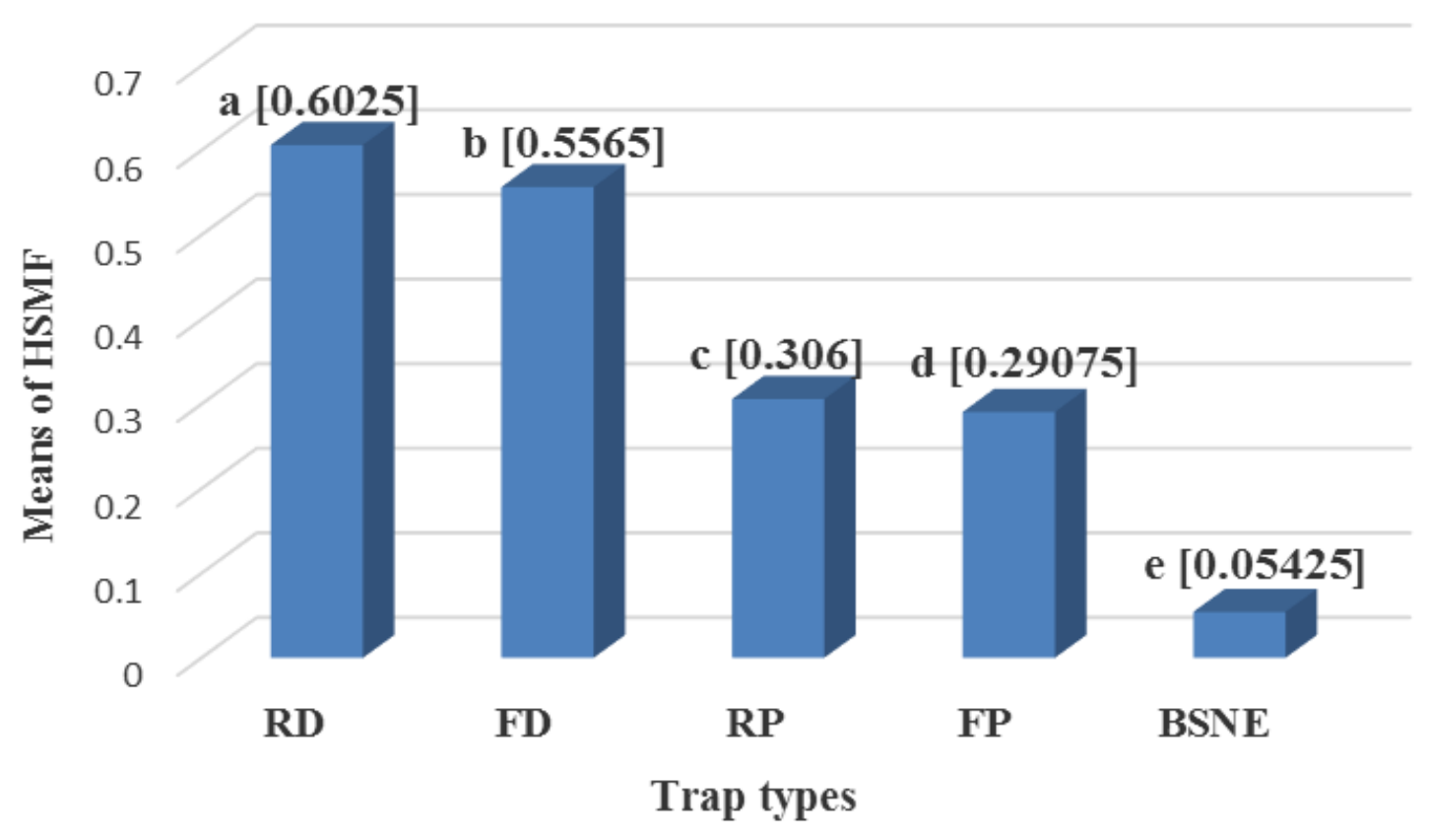

Figure 5. Variation between means HSMF of the trap types and total height; a,b...etc. Means of different letters superscripts are significantly different $(\mathrm{p}<0.05)$

Table 4. Results of the regression analysis between the flux of suspended particles as a function of height

\begin{tabular}{cccc}
\hline Trap types & $\mathbf{a}$ & $\mathbf{b}$ & $\mathbf{R}^{\mathbf{2}}$ \\
\hline $\mathrm{RD}^{*}$ & 60.81 & 0.48 & 0.89 \\
FD $^{*}$ & 62.61 & 0.84 & 0.79 \\
$\mathrm{RP}^{*}$ & 41.32 & 0.55 & 0.69 \\
FP* $^{*}$ & 75.26 & 0.50 & 0.67 \\
BSNE* & 113.22 & 0.35 & 0.66 \\
\hline
\end{tabular}

RD: Rotary Distance trap; FD: Fixed Distance trap; RP: Rotary Point trap; FP: Fixed point trap; BSNE: Big Spring Number Eight Trap $\mathrm{P}=\leq 0.05$.

\subsection{Traps Efficiency for Suspended Particles (E\%)}

Table 5 shows the efficiency of suspension particles for trap types was tested and calibration directly from field measurement. According to [17], the main total soil sediment per year used as a sediment source supply per lateral width (SY). Which, the actual suspension sediment collected of each sampler per each height and each month calculated for mass (m) of suspension particle per year. The suspension efficiency of trap types (E\%), assumed to have $\mathrm{E}=1$ for suspended particle sizes according to [17], was as follow RD> FD> RP> FP> BSNE; 99\%, 98\%, 88\%, $85 \%, 65 \%$ respectively (Fig. 6). Results were performed the Range traps (RD and FD) were more efficiency to collected suspended particles than Point traps (MP and FP). In this context, the efficiency of RD, FD, MP, and FP traps have eliminated one's deficiencies of BSNE trap, which was lower efficiency for fine particles as described by [16].

The variation of the suspension efficiency of traps as a function of height (Fig. 7), Which is the efficiency of RD and FD traps more noticeable increase with height than the RP and FP efficiency respectively. There were no variation approximately between MP and FP traps efficiency with total height. Generally, comparing between tested traps and BSNE trap efficiency as a function of height were more than BSNE efficiency (Fig. 8). This is due to design of traps.

Table 5. Efficiency of suspended particles calculation for RD, FD, RP, FP and BSNE traps in different proposed period (Jan.2020 to Jan.2021) under field measurement:

\begin{tabular}{cccc}
\hline Trap types & $\mathbf{m}^{*}(\mathbf{g})$ & $\mathbf{S Y} * \mathbf{g} / \mathbf{c m}$ width $)$ & $\mathbf{E}^{*}$ \\
\hline RD* & 647.257 & 64859.8 & 0.998 \\
FD* & 155.406 & 3170.384 & 0.98 \\
RP* & 131.915 & 14972.3 & 0.881 \\
FP* & 29.068 & 3407.2 & 0.853 \\
BSNE* & 2.1736 & 329.598 & 0.659 \\
\hline
\end{tabular}

RD: Rotary Distance trap; FD: Fixed Distance trap; RP: Rotary Point trap; FP: Fixed point trap; BSNE: Big Spring Number Eight trap; m: Mass of suspended particles, SY: Total sediment supply per lateral width; E: Efficiency of suspension particle 


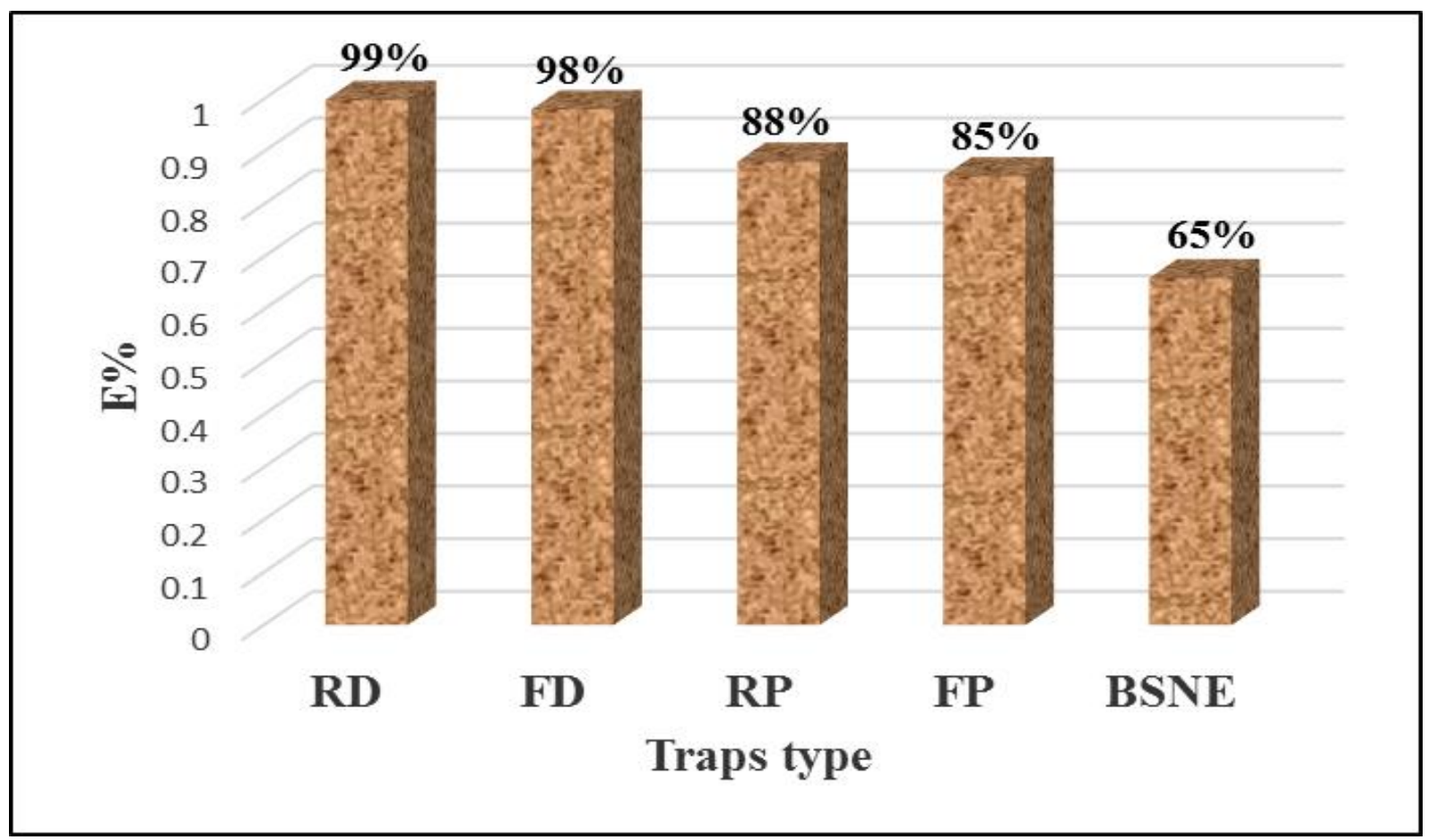

Figure 6. Trap efficiency (\%) of suspended particles

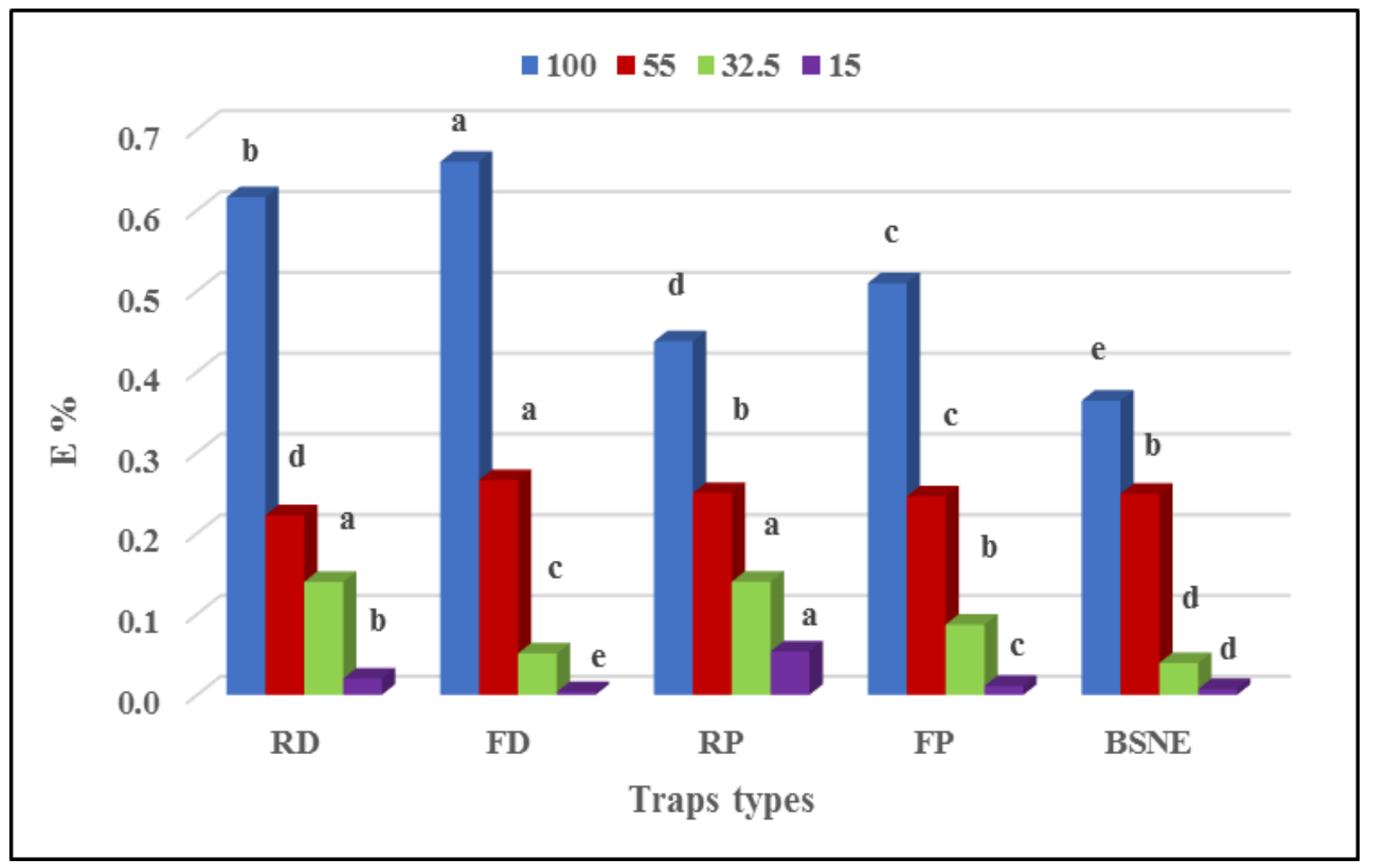

Figure 7. variation between efficiency of suspended particles (E\%) of the trap types and height (10,32.5, 55 and $100 \mathrm{~cm})$; values followed by different letters are significantly at $p<0.05$ 


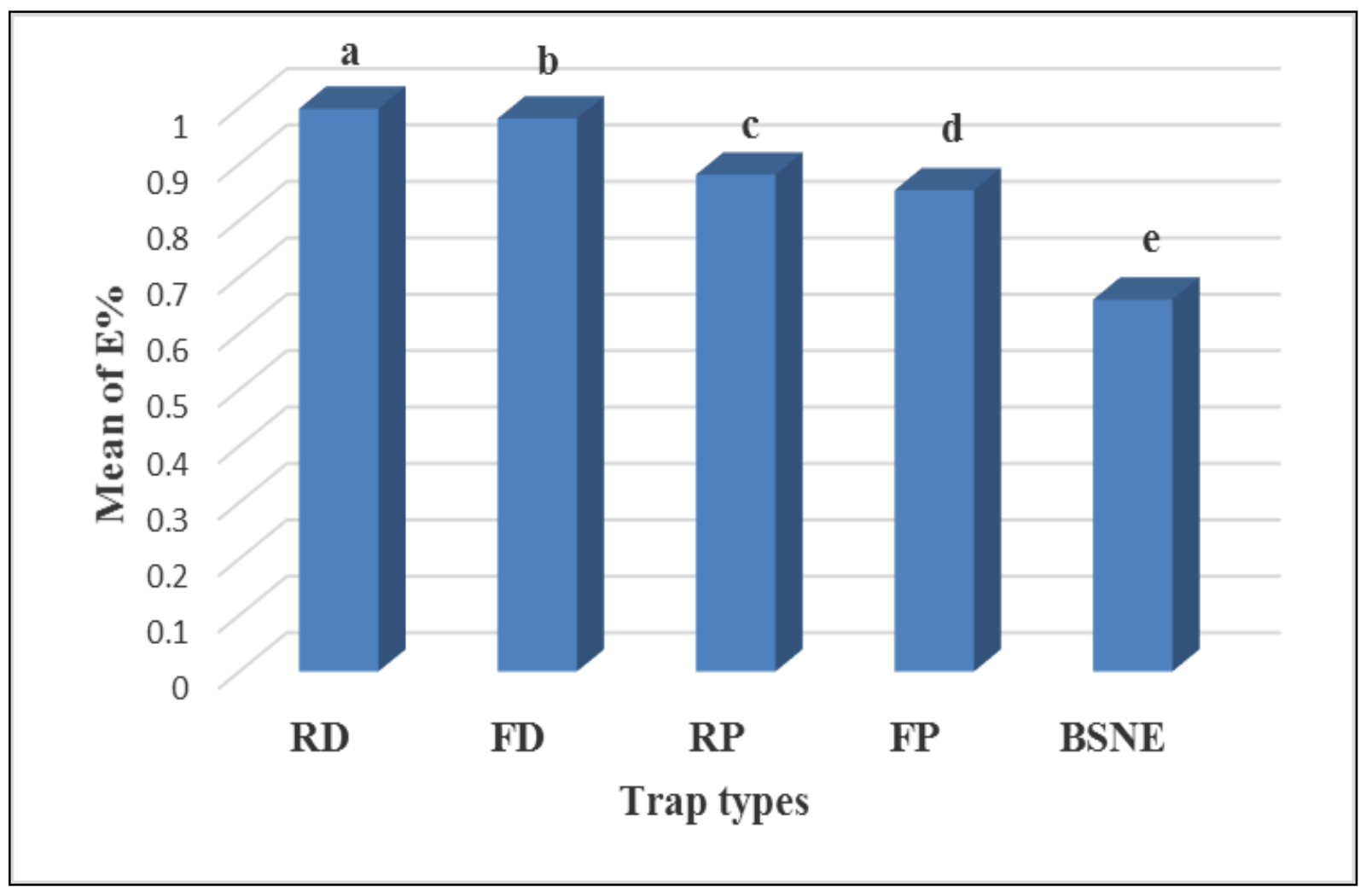

Figure 8. variation between mean efficiency of suspended particles $(\mathrm{E} \%)$ at total heights $(\mathrm{cm})$; values by different letters are significantly at $\mathrm{p}<0.05$

\subsection{Particle Aspects of Trap Efficiency}

Table 6. Results of the regression analysis between all particle size distribution and the particle size distribution of initial soil

\begin{tabular}{cccc}
\hline $\begin{array}{c}\text { Trap } \\
\text { types }\end{array}$ & $\mathbf{a}$ & $\mathbf{b}$ & $\mathbf{R}^{2}$ \\
\hline $\mathrm{RD}^{*}$ & 1.34 & 4.88 & 0.89 \\
FD* & 1.42 & 5.94 & 0.88 \\
RP* & 1.77 & 11.00 & 0.86 \\
FP* $^{*}$ & 1.80 & 11.39 & 0.85 \\
BSNE* $^{*}$ & 0.95 & 0.69 & 0.75 \\
\hline
\end{tabular}

RD: Rotary Distance trap; FD: Fixed Distance trap; RP: Rotary Point trap; FP: Fixed point trap; BSNE: Big Spring Number Eight trap.

The major concern in this section is to calibrate the traps efficiency as a function of particle size for all movement forms particles (suspension - saltation - creeping) by analyzing the size distribution of both trapped particle size distribution of particles and initial soil. The results in Table 6 shows the significant $(\mathrm{P} \leq 0.05)$ of all traps with initial soil in the following order RD $>$ FD $>$ RP $>$ FP $>$ BSNE.

The particle size distribution density (the derivative of the cumulative distribution) is given in (Fig. 9), which shows that more than $60 \%$ (in mass) of size particle have diameter between $<45$ to $100 \mu \mathrm{m}$ (suspension particles). While, about of $35 \%$ (in mass) of size particles more than $100 \mu \mathrm{m}(100$ to $>1000 \mu \mathrm{m})$ which considered as fractions of saltation and creeping particles, respectively. This particles distribution was similar of initial soil texture of the study area. Moreover, particle distribution was extremely fitting in RD, FD, RP, and FP than BSNE traps to initial soil. In this context, the aim of this study about focused of suspension particles because it occupies the largest amount of the particle size distribution of eroded soil, and it is the most dangerous that is agree with [12] (Fig. 9). 




Figure 9. Particle Size distribution densities of the RD, FD, RP, FP and BSNE traps ((1) <45, (2)45-63, (3) 63-100, (4)100-250, (5) 250-500, (6) $500-1000,(7)>1000 \mu \mathrm{m})$

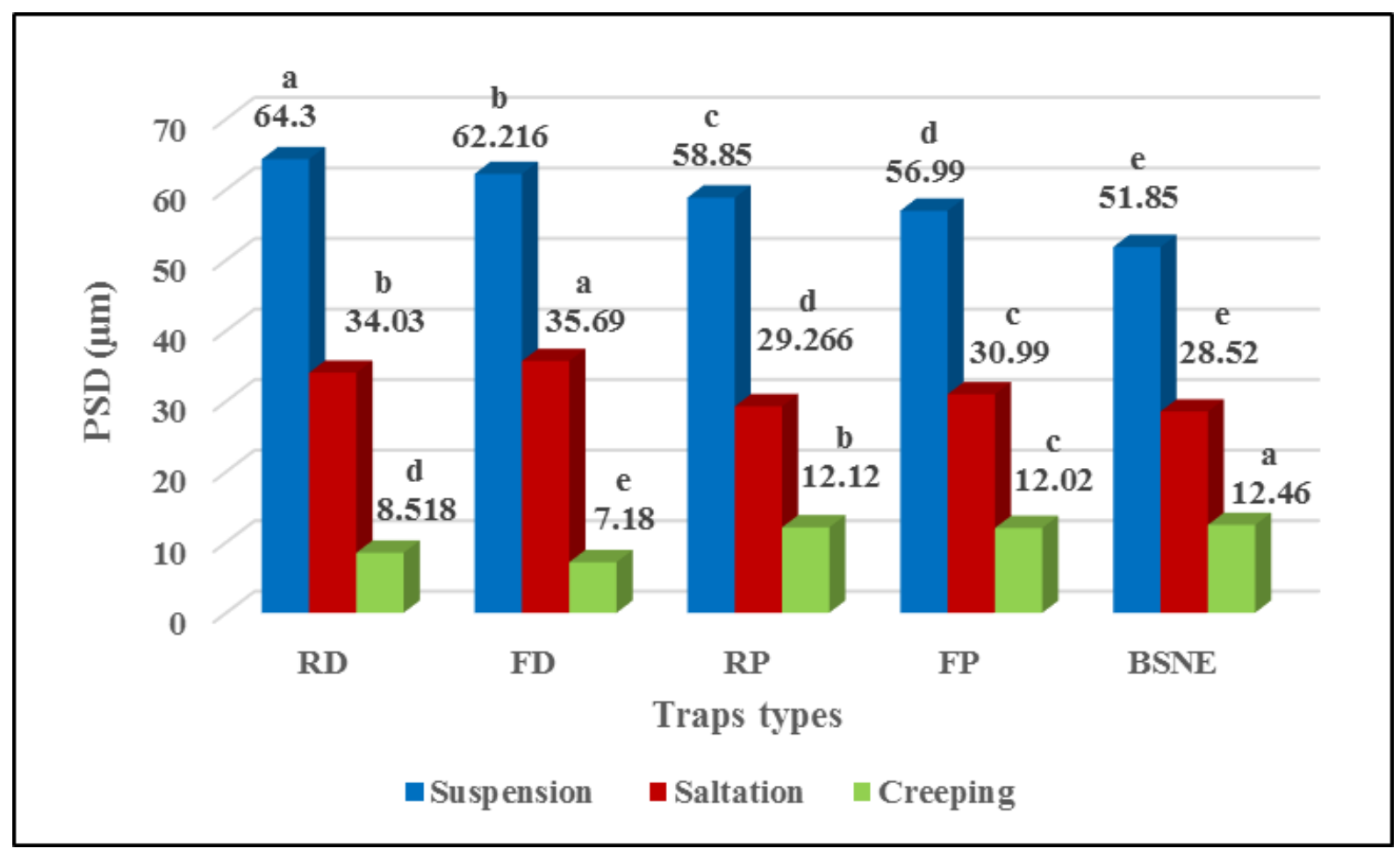

Figure 10. Particle size distribution (PSD) $(\mu \mathrm{m})$ of RD, FD, RP, FP and BSNE traps, Values followed by different letters are significantly at $p<0.05$

The variation of particle size distribution of trap types, was collecting from reservoir box of traps as compared to BSNE (Fig. 10). The eroded material of RD and FD traps more collected suspend particles than RP, FP and BSNE traps this result due to the best collection efficiency was for $\mathrm{RD}$ and FD traps as described by [17] and [24]. In this context, the FD and RD were also the most collecting saltation particles traps. Otherwise, the creeping particles 
collected was as follow BSNE > RP > FP > RD> FD. This result is due to BSNE trap was smallest size of entry hole with compared by all traps. Moreover, due to the absence of a cover for the upper surface which leads to lose the collected of fine soil particles (suspension and saltation) comparing with creeping soil particles. Also, it can be due to sorting during transport with larger particles concentrated at lower levels while finer particles dominate at higher levels. Therefore, it considered as BSNE and point traps (RP and FP) measuring method disadvantages as described by [4] and [16]. On the other hand, the efficiency of traps at the rang particle size of suspension particles $(<45,45-63$ and $63-100 \mu \mathrm{m})$ and there significant between them $(p \leq 0.05)$ [6] and [17] (Fig. 11). The results presented that the RD trap the most efficiency in particle size 63-100 and $<45 \mu \mathrm{m}$. Otherwise, trap efficiency in 45$63 \mu \mathrm{m}$ was as follow $\mathrm{RD}>\mathrm{FD}>\mathrm{RP}>\mathrm{FP}>\mathrm{BSNE}$. These results cleared that the traps measured by distance more efficient than traps measured by point. This is due to the design of RD and FD was the best of collecting weight and collection efficiency and more accurate in measuring of soil loss as described by [24]. In this context, the RD and FD traps were the most efficient as compared to all trap types in all suspended particle size (in mass) especially in the finer particles $(<0.45 \mu \mathrm{m})$. Generally, for the study area, the RD and FD is a quite useful sampler for field measurements as compared to the rest of traps.

presented that the RD trap the most efficiency in particle size 63-100 and $<45 \mu \mathrm{m}$. Otherwise, trap efficiency in 45$63 \mu \mathrm{m}$ was as follow $\mathrm{RD}>\mathrm{FD}>\mathrm{RP}>\mathrm{FP}>\mathrm{BSNE}$. These results cleared that the traps measured by distance more efficient than traps measured by point. This is due to the design of RD and FD was the best of collecting weight and collection efficiency and more accurate in measuring of soil loss as described by [24]. In this context, the RD and FD traps were the most efficient as compared to all trap types in all suspended particle size (in mass) especially in the finer particles $(<0.45 \mu \mathrm{m})$. Generally, for the study area, the RD and FD is a quite useful sampler for field measurements as compared to the rest of traps.

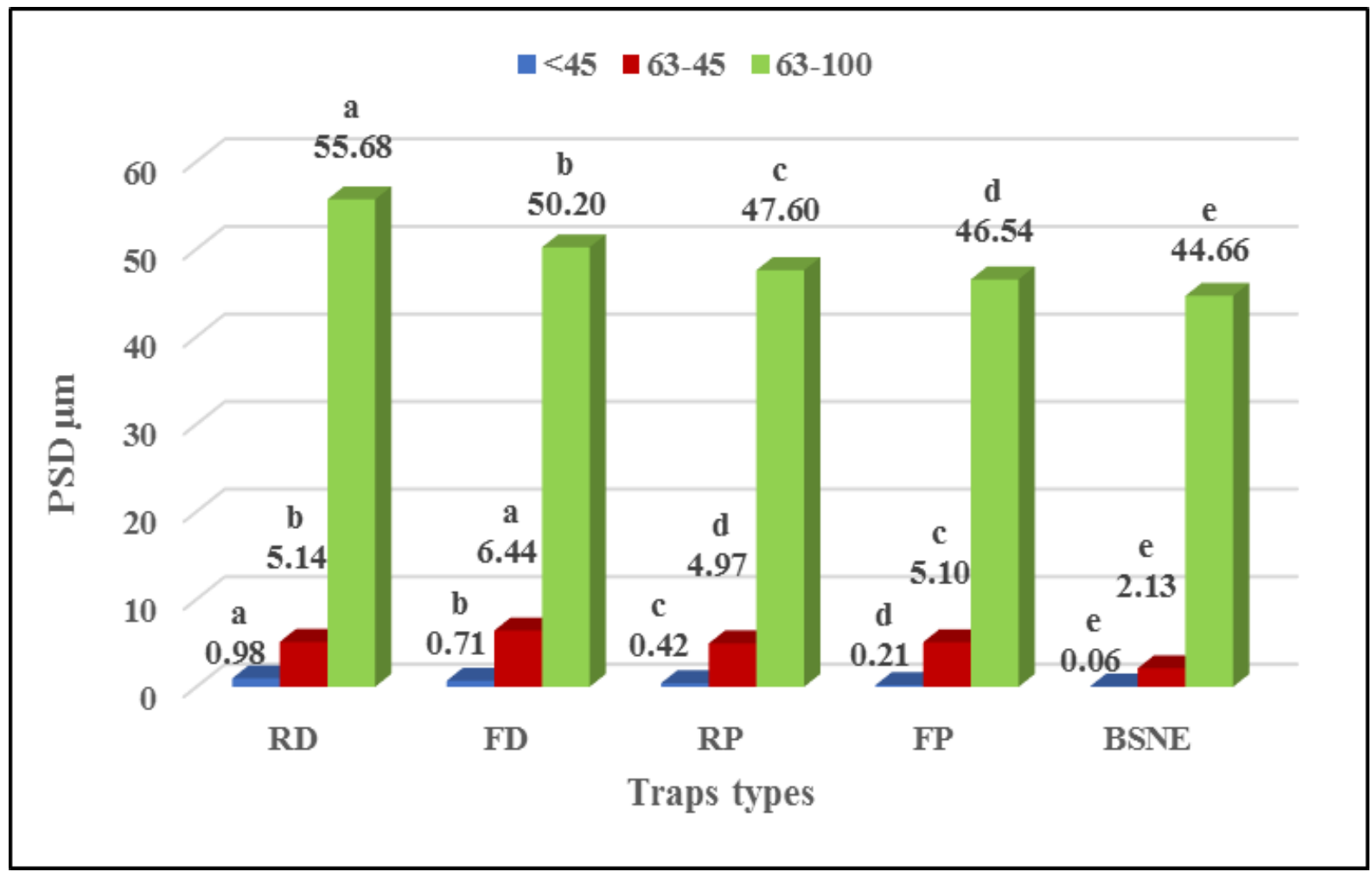

Figure 11. Particle size distribution of suspended particles at RD, FD, RP, FP and BSNE, Values followed by different letters are significantly at $p<$ 0.05 . 




Figure 12. Variation of particles size distribution of RD, FD, and BSNE

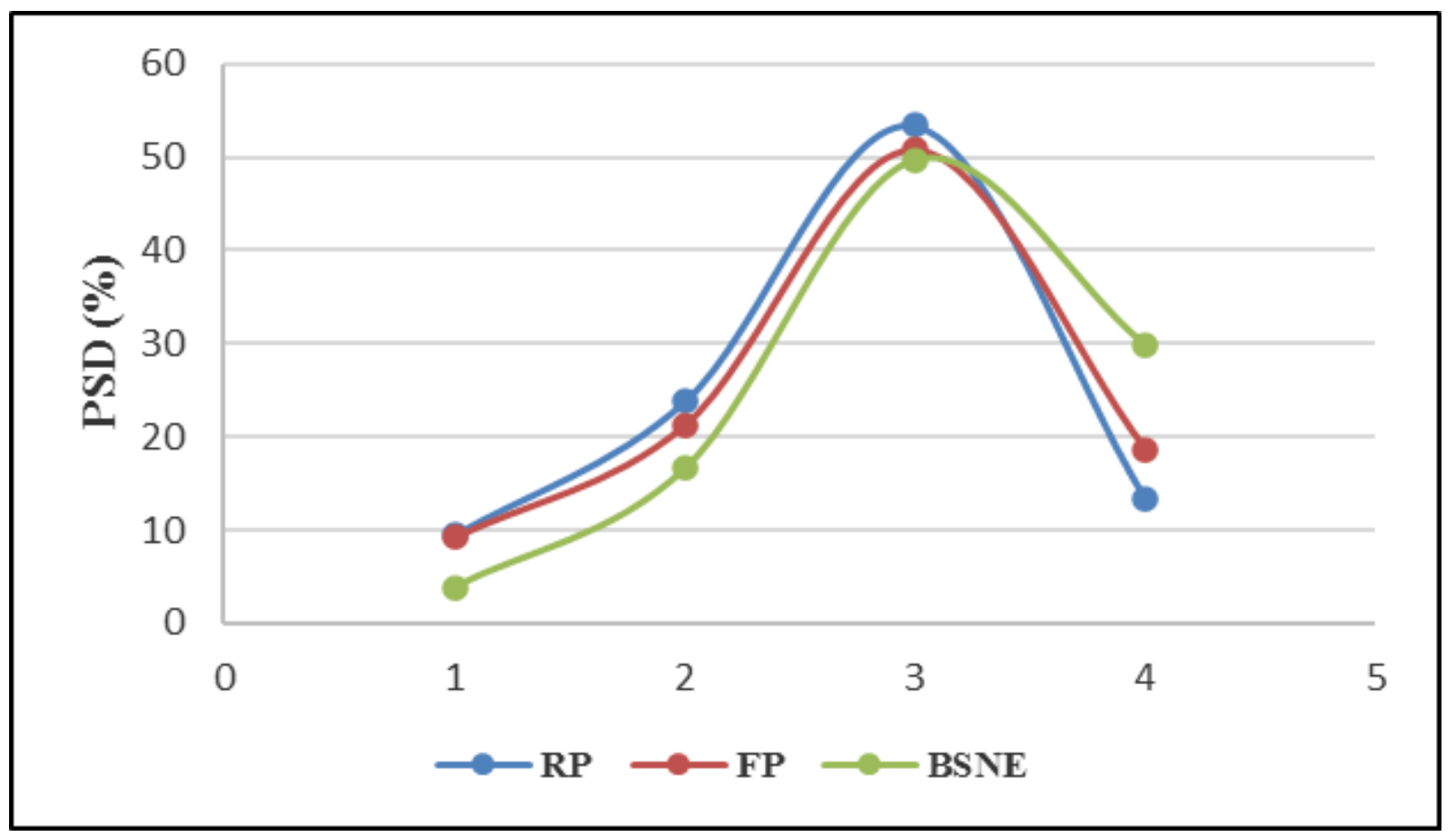

Figure 13. Variation of particles size distribution of RP, FP and BSNE

A part forms the trap suspended particle efficiency calibration; the other aspects listed above will also be reflected in the suspended particle size analysis of sediments traps. As shown in Fig. 12 and 13 the distribution of suspended particle size range (in mass) less than $100 \mu \mathrm{m}$ collected by RD, FD, RP, and FP traps comparing with sediments collected by BSNE trap this similar with [17]. The result shows the RP and FP more like BSNE than RD and FD traps. In particular, the RD, FD traps were the highest efficiency and the most accuracy the modal size range of the soil at $<100 \mu \mathrm{m}$ (in mass). Which, it is supplies most of the suspension particles size. $\mathrm{RD}>\mathrm{FD}>$
RP> FP traps discriminate between small particles comparing with BSNE. So, the RD and FD traps were the easiest and fastest traps in a direct way for analyzing suspended particle size distribution.

\section{Conclusion}

The aim of this study was investigated the suspension efficiency as a function of particle size distribution and as a function of height for four sediment traps to soil loss wind erosion measurements. Which these traps were in passive 
and vertical kind of traps. In this study, measured the horizontal suspended mass flux (HSMF) for one year in Wadi El Raml at NWCZ. The results of HSMF showed that the positive relationship and high significant effect $(\mathrm{p} \leq$ $0.05)$ with the different height $(10,32.5,55,77.5,100)$ of soil surface. Also, we measured the efficiency of each trap of collecting and measuring of suspended particles and used calibration as a direct comparison with initial soil of study area. Each trap was comparing with BSNE as a suspended efficiency and the efficient of each trap as a function of particle size distribution. The RD and FD traps were the most efficient of all trap types in all suspended particle size (in mass) especially in the finer particles $(<0.45 \mu \mathrm{m})$.

It can be concluded that the beneficial effect of designing RD, FD, RP, FP traps can be overcoming of some disadvantages of BSNE trap. The BSNE was the lowest suspended efficient for particles smaller than $45 \mu \mathrm{m}$ (suspension or dust particles). The RD and FD traps were the most acceptable for suspended particle size and the quietest useful sampler for field measurements in the study area. Because of a direct, accuracy and easy way for measuring all eroded soil particles collecting especially the suspended particles.

In the future studies, recommended the RD and FD traps for examined the suspended particles flux. Especially, when studying suspended soil particles and its impact on causing environmental pollution, reduce agricultural development and harmful to human health.

\section{REFERENCES}

[1] Yang, X.; He, Q.; Ali, M.; Huo, W. and Liu, X., "Near-surface sand - dust horizontal flux in Tazhong - the hinterland of the Taklimakan desert". J. Arid land, 5(2):199-206, 2013. DOI:10.1007/s40333-013-0159-x

[2] McTainsh, G.; Strong C.; "The role of aeolian dust in ecosystems". Geomorphology J., 8(9) 39-54, 2007. DOI: 10.1016/j.geomorph.2006.07.028

[3] Liu, T. S., "Loess and Arid Environment". Hefei: Anhui Science and Technology press Pages515-537, 2009. Doi:org/10.1144/qjegh2009-054.

[4] Goossens, D.; and Buck, B. J., "Can BSNE (Big Spring Number Eight) samplers be used to measure PM10, respirable dust, PM 2.5, and PM 1.0?" Aeolian Research 5: 43-49, 2012. DOI: 10.1016/j.aeolia.2012.03.002

[5] Yildiz S.; Enç V.; Kara M.; Tabak Y., and Acet E., "Assessment of the potential risks of airbone microbial contamination in solid recovered fuel plants: A case study in Istanbul. Environ. Eng”. Manag. J., 16: 1415-1421, 2017. Doi:org/10.30638/eemj.

[6] Yang, X.; Wang, M.; He, Q.; Mamtimin, A.; Huo, W.; Yang, F. and Zhou, C.; "Estimation of sampling efficiency of the Big Spring Number Eight (BSNE) sampler at different heights based on sand particle size in the Taklimakan
Desert".Geomorphology j. 3(22):89-96, 2018. Doi:org/10. 1016/j.geomorph.2018.08.042

[7] FAO, "Soil erosion the greatest challenges for sustainable soil management"www.fao.org/publications Rome. 2019, pp 100.

[8] Abdoli, S.; Khalilimoghadam, B.; Rahnama, M., and Soleimani, M., "Comparison of different mass transport equations for wind erosion quantification purposes in southwest Iran: A wind tunnel study" Desert J online 22(2): 197-208, 2017. http:// desert.ut.ae.ir.

[9] FAO (Food and Agriculture Organization of the United Nations). "Status of the World's Soil Resources" Main Report - Chapter6 - Global Soil Status, Processes, and Trends. - Food and Agriculture Organization of the United Nations and Intergovernmental Technical Panel on Soils, PP 313-325, 2015.

[10] Fryrear, D. W.; Wassif, M. M.; Tadrus, S. F. and Ali, A. A. "Dust measurements In the Egyptian Northwest Zone" Trans. ASABE, 51(4):1252-1262, 2008. DOI https://agris.fao.org/agri/search.do?recordID=US20130158 5969

[11] Omnia Wassif, M.; Meselhy A. A.; Sharkawy, S.F.; and Ali, A. A. "quantify impact of wind erosion on organic matter content under management practices, wadi El Raml, NWCZ”, Egypt Egyptian J. Desert Res., 70, No. 1, 83-102, 2020. DOI: $10.21608 /$ ejdr.2020.33688.1073

[12] Zabihi, F; Esfandiari, M; Dalalian, M.R. and Moeini, A., "Horizontal flux of Suspended Particles Sampling by Big Spring Number Eight (BSNE) Sampler in Lake Urmia area". Applied ecology and Environmental Research 16 (2) 1313-1327, 2018. DOI: 10.15666/aeer/1602_13131327

[13] Shao, Y.P., "Physics and Modelling of Wind Erosion". 2 ed vol. 37 pp.447, 2008. Springer-Verlag, New York F w www.springer.com/series/5669.

[14] Mendez, M. J.; Funk, R. and Buschiazzo, D. E., "Field wind erosion measurements with Big Spring Number Eight (BSNE) and Modified Wilson and Cook (MWAC)sampler s".Geomorphology J.129:(2)43-48,2011.DOI: 10.1016/j.

[15] Dong, Z.B., Man, D.Q., Luo, W.Y., Qian, G.Q., Wang, J.H., Zhao, M., Liu, S.Z., Zhu, G.Q., Zhu, S.J., "Horizontal aeolian sediment flux in the Minqin area, a major source of Chinese dust storms". Geomorphology J. 1(16): 58-66, 2010. DOI: 10.1007/s00704-016-1917-4

[16] Azimzadeh, H.R. and Ekhtesasi, M.R., "A study on Isatis suspension trap efficiency; Advantages and disadvantages". Desert j. online: 16:123-131, 2011. http://jdesert.ut.ae.ir

[17] Shao, Y.; McTainsh, G. H. and Leys, J. F., "Efficiencies of sediments samplers for wind erosion measurement. Soil and Water management and conservation". Aust. J. Soil Res., 3(1):519-532. 1993. http://dx.DOI:.org/10.1071/SR993051 9

[18] Mendez, M. J.; Funk, R. and Buschiazzo, D. E., "Efficiency of Big Spring Number Eight (BSNE) and Modified Wilson and Cook (MWAC) samplers to collect PM10, PM 2.5 and PM1" Aeolian Research J., 21:37-44, 2016. DOI: 10.1016/j.aeolia.2016.02.003

[19] Guerrero, R.; Valenzuela, J. L.; Torres, J. L.; Lozano, J. and Asensio, C., "Soil wind erosion characterization in 
south-eastern Spain using traditional methods in front of an innovative type of dust collector" International Agrophysics J. 34, 503-510, 2020. DOI: https://doi.org/10.31545/intagr/131099

[20] Goossens D., Offer Z., and London G., "Wind tunnel and field calibration of five aeolian sand traps". Geomorphology J,35: 233-252, 2000. https://DOI:org/10.1 $016 / \mathrm{s} 0169-555 \mathrm{x}(00) 00041-6$

[21] Fryrear, D. W., "Mechanics of erosion: measurement, prediction and control soil, water and crop / livestock management systems for rainfed agriculture in the Near East Region". Proceedings of the workshop at Amman, Jorden, January 18-23:136-146, 1986. (India): ICRISAT, ISBN 92-9066 https://agris.fao.org/agris-search/search.do? recordID $=\mathrm{QX} 8800138$

[22] Klute, A., "Methods of Soil Analysis". Part (1): Physical and Mineralogical Methods. in the Agronomy Series. Amer Soc. of Agron. And Soil Sci. Soc. of America (publisher), Second Edition. Madison, Wisconsin, USA. No.9, 1986. https://DOI.org/10.1002/gea.3340050110

[23] National Centers for Environmental Information(NCEI)htt ps://www.ncei.noaa.gov. 2020.

[24] Meselhy, A. A. and Omnia Wassif, M., "Manufacturing and assessing new samplers to measure wind soil erosion". Journal of Applied and natural science ANS (An international journal (Online). 13(4): 432 - 449, 2021. https://journals.ansfoundation.org/index.php/jans

[25] Fryrear, D. W.; Stout, J. E.; Hagen, L, J, and Vories, E. D.,
"Wind erosion: field measurement and analysis soil and Water" Div. of ASAE presented as ASAE Paper 34(1):155-160, 1991. DOI:org/0149-9890inta/gr/ 1502564.

[26] Wang, G., Wanquan, T., Mingyuan, D., "Flux and composition of wind-eroded dust from different landscapes of an arid inland river basin in north-western China" Journal of Arid Environments 58: 373-385, 2004. DOI: http://dx.doi.org/10.15666/aeer/1602_13131327

[27] SAS, "Statistical Analysis System", User's Guide, Statistical version. 8th Edition, SAS Institute, Cary, 2004. https://support.sas.com/documentation/onlinedoc/91pdf/sa sdoc_91/stat_ug_7313.pdf

[28] Duncan, D. B., "Multiple range and multiple F- test" Biometrics, 11: 1-42., 1955. https://doi.org/10.2307/30014 78. https://www.jstor.org/stable/3001478

[29] Wassif M. M.; Draz, M. Y.; Elasker, M. Kh. and El-Maghraby, S.E.1. "Quantify and properties of soil loss by wind erosion in South Sinai". Egypt. J. Soil Sci. 39 (3): 315-323, 1999. https://agris.fao.org/agris-search/search.do ?recordID=EG2000002744

[30] Farrell, E.J., Sherman, D.J., Ellis, J.T., Li, B., "Vertical distribution of grain size for windblown sand". Aeolian Res. 7, 51-61. 2012. DOI: 10.1016/j.aeolia.03.003

[31] Fryrear, D. W. and Saleh, A. "Field wind erosion: vertical distribution". Soil Science J. 155(4): 294-300, 1993 https://journals.lww.com/soilsci/Abstract/1993/04000/FIE LD_WIND_EROSION_VERTICAL_DISTRIBUTION.8 .aspx 